\title{
Differential Expression of Mcp-1 and Its Receptor CCR2 in Glucose Primed Human Mesangial Cells
}

\author{
Ulf J anssen ${ }^{a}$ Eveline Sowab Petra Marchand ${ }^{b}$ J ürgen Floege ${ }^{a}$ \\ Aled O. Phillips ${ }^{c}$ Heinfried H. Radeked \\ a Division of Nephrology, University of Aachen, and bepartment of Pharmacology, Medizinische Hochschule, \\ Hannover, Germany; ' Institute of Nephrology, University of Wales College of Medicine, Cardiff, UK; \\ dPharmazentrum Frankfurt, Clinic of J .W. Goethe University, Frankfurt, Germany
}

\section{Key Words}

Monocyte chemoattractant protein-1 - CCR2 - Glucose • Mesangial cell

\begin{abstract}
Background: Glomerular mononuclear cell infiltration is associated with the development of a diffuse glomerulosclerosis in patients with diabetic nephropathy. Monocyte chemoattractant protein-1 (MCP-1) plays an important role in the recruitment and accumulation of monocytes and lymphocytes within the glomerulus. In the present study, we examined whether the ambient glucose concentration alters the expression of MCP-1 and its receptor CCR2 in primary human mesangial cells (HMC). Methods: MCP-1 mRNA expression was assessed by Northern blot and CCR2 mRNA expression by RT-PCR analysis. MCP-1 protein production was determined by ELISA. Migration studies were performed to assess functional MCP-1 receptor expression. Results: Exposure of HMC to $30 \mathrm{mM}$ D-glucose led to a $30 \%$ increase in MCP-1 mRNA expression as compared to $5 \mathrm{mM}$ D-glucose and osmotic controls while there was no difference in MCP-1 protein production. Simultaneously, CCR2 mRNA expression was down-regulated in
\end{abstract}

HMC exposed to $30 \mathrm{mM}$ D-glucose. $5 \mathrm{mM}$ D-glucose primed HMC showed a dose-dependent migration towards MCP-1 that was dose-dependently inhibited by pertussis toxin, the broad-spectrum chemokine antagonist VMIP-II as well as the CCR2 receptor antagonist (18del)MCP-1 - demonstrating functional activity of MCP-1 receptor expression in primary $\mathrm{HMC}$. In accordance with the downregulatory effects of $30 \mathrm{mM}$ D-glucose on CCR2 mRNA expression no migratory response towards MCP1 was observed under these conditions. The additional proinflammatory stimulus TNF $\alpha$ increased MCP-1 protein production in 30 as compared to $5 \mathrm{mM}$ D-glucose primed HMC $(2,194 \pm 568$ vs. $1,422 \pm 379$ pg MCP-1/104 cells $\times \mathrm{ml}$ in 30 vs. $5 \mathrm{mM}$ D-glucose primed $\mathrm{HMC}+24 \mathrm{~h}$ TNF $\alpha 500 \mathrm{U} / \mathrm{ml}, \mathrm{p}=0.002$ ). However, this was not associated with an increased MCP-1 mRNA transcription. The $30 \mathrm{mM}$ D-glucose induced downregulation of CCR2 mRNA expression was prevented in the presence of TNF $\alpha$. Conclusion: High ambient glucose does not affect mesangial MCP-1 release and decreases its CCR2 receptor expression. However, in the presence of an inflammatory stimulus these effects of high glucose are reversed and an autocrine pathway of MCP-1 develops in mesangial cells.

Copyright $\odot 2002$ S. Karger AG, Basel

\begin{tabular}{ll}
\hline KARGER & ( 2002 S. Karger AG, Basel \\
Fax +416130612 34 & 0028-2766/02/0924-0797\$18.50/0 \\
E-Mail karger@karger.ch & Accessible online at: \\
www.karger.com & www.karger.com/journals/nef
\end{tabular}

\author{
Ulf Janssen, MD \\ Medizinische Klinik II, University of Aachen \\ Pauwelsstrasse 30 \\ D-52057 Aachen (Germany)
}

Tel. +49 2418089530, Fax +49 2418082446 


\section{Introduction}

In patients with diabetic nephropathy infiltration of the glomerulus with macrophages is closely related to the development of a diffuse glomerulosclerosis [1]. Chemokines play a central role in the chemotaxis and activation of leukocytes. In patients with diabetic nephropathy increased urinary monocyte chemoattractant protein-1 (MCP-1) levels in the presence of normal serum levels have been described $[2,3]$ - suggesting a local production of MCP-1 in the kidney in diabetic nephropathy. MCP-1 is one of the main chemokines expressed by human mesangial cells [4] and responsible for the bulk of their chemotactic activity in vitro [5]. Resting HMC show only little basal secretion of MCP-1 that is up-regulated upon stimulation with proinflammatory cytokines such as interleukin-1 $\beta$ (IL-1 $\beta$ ), tumor necrosis factor- $\alpha(\mathrm{TNF} \alpha)$ or interferon- $\gamma$ (INF $\gamma$ ) [4]. Moreover, increased MCP-1 secretion in HMC has been observed after stimulation with low-density lipoproteins [6], thrombin [7] and glycated albumin [3].

Major effects of MCP-1 are mediated by its receptor CCR2 [8]. Apart from leukocytes [8, 9] CCR2 expression is found in vascular smooth muscle cells [10], endothelial cells $[11,12]$ and fibroblasts $[13,14]$. An upregulation of CCR2 expression in fibroblasts derived from fibrotic pulmonary granulomas has been observed [13]. It is therefore conceivable that MCP-1 and CCR 2 may play a role in the development of the glomerular sclerotic and fibrotic changes in progressive diabetic nephropathy. While no consistent CCR2 expression has been observed in an immortalized human mesangial cell line [15] we provide evidence that primary human mesangial cells show a functionally active MCP-1 receptor expression. The aim of the current study was to investigate the effect of the ambient glucose concentration and additional proinflammatory stimuli on MCP-1 and CCR2 expression in primary human mesangial cells.

\section{Materials and Methods}

\section{Human Glomerular Mesangial Cell Preparation and}

Characterization

For the present experimental series, selected tumor-free, healthy tissue of kidneys from different donors undergoing tumor nephrectomy (who had given their informed consent) were obtained freshly with the help of the Department of Urology, Hannover Medical School. Human mesangial cells were prepared as described [16, 17] The different specimens showed no significant differences in growth, proliferation and morphology. Characterization by immunofluorescence staining showed a positive reaction for SMC-myosin and actin, vimentin, fibronectin, desmin and type IV collagen, a negative reaction for antihuman keratin, factor VIII and MHC class II antisera. There was no morphological evidence of the presence of macrophages (pseudopodia), endothelial-like cells (cobblestone) or fibroblasts. Additionally, by means of biochemical characterization bone marrow-derived resident macrophages and endothelial cells could be effectively disclosed by the following criteria: HMC were MHC class II negative [18], showed a typical profile of prostanoids [19, 20], and in contrast to macrophages did not express 5-lipooxygenase mRNA or produce leukotrienes [19], and unactivated HMC released no reactive oxygen species [16, 21]. Furthermore, the use of HMC between passages 6 and 8 excluded macrophage as well as endothelial cell contamination, as these cell types do not survive multiple passaging under the described medium conditions.

Culture Conditions and Stimulation of Human Mesangial Cells After the third passage HMC were grown, as described [16, 21], in RPMI-1640 supplemented with nonessential amino acids $(1 \mathrm{ml} / \mathrm{dl})$, $L$-glutamine $(2 \mathrm{mM})$, sodium pyruvate $(1 \mathrm{mM})$, transferrin $(5 \mu \mathrm{g} /$ $\mathrm{ml})$, insulin $(125 \mathrm{U} / \mathrm{ml})$ and FCS $(10 \%)$. Cells were grown at $37^{\circ} \mathrm{C}$ in $5 \% \mathrm{CO}_{2}$ and $95 \%$ air. For passaging HMC were detached by trypsinEDTA $(0.125 \% / 0.01 \% \mathrm{w} / \mathrm{v})$ and split into $1: 3$ (culture media and supplements were obtained from Gibco BRL, Eggenstein, Germany). Cells were grown to confluence and serum deprived for $72 \mathrm{~h}$ prior to experimental manipulation. All experiments were performed under serum-free conditions. Resting medium consisted of RPMI-1640 supplemented with nonessential amino acids $(1 \mathrm{ml} / \mathrm{dl}), L$-glutamine ( $2 \mathrm{~m} M)$, sodium pyruvate $(1 \mathrm{mM})$, transferrin $(5 \mu \mathrm{g} / \mathrm{ml})$, insulin (125 U/ml), containing 0.5\% BSA (IgG free, low endotoxin, Sigma, Deisenhofen, Germany) and $5 \mathrm{~m} M D$-glucose without any FCS. Confluent, 'growth-arrested' HMC were stimulated with $30 \mathrm{~m} M D$-glucose for times up to $48 \mathrm{~h}$. In control experiments cells were exposed to either $5 \mathrm{~m} M D$-glucose or $30 \mathrm{~m} M L$-glucose as the 'normal glucose' and 'hyperosmolar' controls, respectively. To examine the effects of additional proinflammatory stimuli on glucose primed HMC recombinant human (rh) TNF $\alpha$ (Phillips, Bissendorf, Germany) was added to the cells.

Ribonucleic Acid (RNA) Isolation, Reverse Transcription (RT), and Polymerase Chain Reaction (PCR) Amplification

For isolation of RNA, the cells were washed twice in ice-cold PBS, and total RNA was isolated using the RNA-Clean System (Angewandte Gentechnologie Systeme, Heidelberg, Germany). Reverse transcription (RT) and polymerase chain reaction (PCR) amplification were performed as previously described $[22,23]$. Total RNA $(1 \mu \mathrm{g})$ was reverse transcribed and amplification of the resulting cDNA was performed for a submaximal number of cycles (36 cycles for CCR2, 28 for $\beta$-tubulin) in a Varius VR thermocycler (Landgraf, Hannover, Germany). The PCR products were analyzed on $1.5 \%$ agarose gels and bands were visualized by ethidium bromide staining. $\beta$-Tubulin is constitutively expressed by HMC and served as a control for RT-PCR [23]. The amplification primers based on the known sequences of human cDNA were as follows: CCR2 sense was 5'-ATGCTGTCCACATCTCGTTCTCGGT-3', antisense was 5'CGTTTTATAAACCAGCCGAGACTT- ${ }^{\prime}$, product size $1,087 \mathrm{bp}$ [24]; $\beta$-tubulin sense was $5^{\prime}$-TTCCCTGGCCAGCT(GC)AA(AGCT)GC(AGCT)GACCT(AGCT)CGCAAG-3', antisense was 5'-GTACGGGAGCGG(AGCT)CACATGGTCAC(AGCT)T(AGCT)CTTCCG-3', product size 486 bp [23]. Primers were purchased from MWG-BIOTECH, Ebersberg, Germany. 
Northern Blot Analysis

Total cellular RNA from HMC (10 $\mu \mathrm{g} / \mathrm{lane})$ was electrophoresed through formaldehyde-agarose gels, transferred onto nylon membrane, and hybridized with digoxigenin-labelled RNA probes specific for human MCP-1 [25]. The probes were labeled using the DIG RNA Labelling Kit, and detection of nucleic acids was performed with the DIG Chemiluminescent Detection Kit (both reagents were from Roche Molecular Biochemicals). The resulting bands were quantitated by densitometry. The relative optical density (OD) of the MCP-1 bands were normalized using the $28 \mathrm{~S}$ band as control.

Determination of MCP-1 Levels in Mesangial Cell Supernatants

At the end of each experiment cell supernatants were collected and cells were detached with trypsin-EDTA $(0.125 \% / 0.01 \% \mathrm{w} / \mathrm{v})$. Complete removal of cells was monitored throughout by phase-contrast microscopy. Viable cells were counted after staining with trypan blue. The concentration of secreted MCP-1 in the supernatants was determined by ELISA. ELISA analysis was performed using reagents from R+D Systems (Minneapolis, Minn., USA) according to the instructions of the manufacturer. Each data point was determined in duplicate.

\section{Migration Assay}

To assess the functional relevance of CCR 2 expression in HMC, migration studies were performed. In these experiments cell culture inserts with polyethylene terephtalate (PET) membranes (pore size $8 \mu \mathrm{m}$ ) were used (Becton Dickinson, Meylan Cedex, France). The membranes were coated with $100 \mu \mathrm{l}$ type IV collagen (Sigma) $100 \mu \mathrm{g} / \mathrm{ml}$ and then air-dried. Confluent, 'growth-arrested' HMC were exposed to 5 or $30 \mathrm{mM} D$-glucose for $48 \mathrm{~h}$ in the absence of serum. Subsequently, the cells were trypsinized, counted and kept in culture medium containing 5 or $30 \mathrm{mM} \mathrm{D}$-glucose for $2 \mathrm{~h}$ at $37^{\circ} \mathrm{C}$ under occasional gentle agitation until the assay. Resting medium supplemented with the respective glucose concentration with rhMCP-1 (test wells) or without rhMCP-1 (control wells) was pipetted into the wells of a 24 -well plate $(1 \mathrm{ml} /$ well). The coated cell culture inserts were transferred into the wells containing control or test medium. Immediately, $100 \mu \mathrm{l}$ of resting medium supplemented with the respective glucose concentration was pipetted into the inserts and 100,000 cells in a total volume of $30 \mu 1$ medium were added to each insert.

Plates were incubated at $37^{\circ} \mathrm{C}$ and $5 \% \mathrm{CO}_{2}$ in air for $16 \mathrm{~h}$. Following incubation, inserts were gently removed, and the cells that had migrated into the bottom wells were photographed using a Polaroid Micro SLR Microscope Camera. Migration was quantified as the mean number of migrated cells observed in two high power fields. For each set of conditions, observations in three different wells were averaged. The cells that had migrated to the bottom well were counted and expressed as a migration index (M. Index), calculated as the $\mathrm{X}$-fold increase in migration (test wells) observed over the negative control (control wells).

To assess whether the migration of HMC towards MCP-1 is mediated via a pertussis-toxin sensitive pathway $5 \mathrm{~m} M D$-glucose primed HMC were preincubated with pertussis-toxin at various concentrations or media alone for $1 \mathrm{~h}$ and migration was assessed in the presence of the toxins as described above. The influence of the broadspectrum chemokine antagonist viral macrophage inflammatory protein (vMIP)-II as well as the CCR2 receptor antagonist murine (1$8 \mathrm{del}$ ) MCP-1 on the MCP-1 triggered migration of HMC was investigated in the same way. vMIP-II and murine (1-8del) MCP-1 have been expressed and purified in our laboratory from the respective transduced Pichia pastoris clones as previously described by others [26] and the bio- and binding-activity of MCP-1 ligands across murine and human species we exploited here has been demonstrated before [27].

\section{Statistical Analysis}

Values are expressed as mean \pm SD. Values were compared using either the Kruskal-Wallis test or Mann-Whitney U test. Statistical significance was defined as $\mathrm{p}<0.05$.

\section{Results}

\section{Exposure of HMC to High Glucose Up-Regulates \\ MCP-1 mRNA but Not Protein Expression}

$30 \mathrm{~m} M D$-glucose alone led to a $30 \%$ increase in MCP$1 \mathrm{mRNA}$ expression after $48 \mathrm{~h}$ as compared to $5 \mathrm{~m} M D$ glucose and osmotic controls (fig. 1a). However, no significant difference in MCP-1 secretion was observed between 30 and $5 \mathrm{~m} M D$-glucose primed HMC after 24 and $48 \mathrm{~h}$ (fig. 1b).

\section{Exposure of HMC to High Glucose Downregulates CCR $2 \mathrm{mRNA}$ Transcription and Migration of HMC Towards MCP-1}

$30 \mathrm{~m} M D$-glucose alone led to a complete abrogation of CCR2 mRNA expression after $48 \mathrm{~h}$ as compared to $5 \mathrm{mM}$ $D$-glucose and osmotic controls (fig. 2a). Functional activity of CCR2 receptor expression by HMC was demonstrated by three approaches. First of all MCP-1 moderately but significantly stimulated migration of $5 \mathrm{~m} M D$-glucose primed HMC in a dose-dependent manner (fig. $2 b$ ). Secondly the effect of MCP-1 on the migration of $5 \mathrm{mM}$ $D$-glucose primed HMC was dose-dependently blocked by pertussis-toxin treatment, indicating the involvement of a pertussis-toxin sensitive $\mathrm{G}$ protein in this process (fig. $2 \mathrm{c}$ ). Finally, MCP-1 induced migration of $5 \mathrm{~m} M D$-glucose primed HMC was concentration-dependently inhibited by the broad-spectrum chemokine antagonist vMIP-II as well as the CCR2 receptor antagonist (1-8del)MCP-1 (fig. 2d). In accordance with the effects of high glucose on CCR2 mRNA levels in nonstimulated HMC (fig. 2a) priming of $\mathrm{HMC}$ with $30 \mathrm{~m} M D$-glucose completely abrogated the MCP-1 induced HMC migration to control levels (fig. 2d; second data set). 

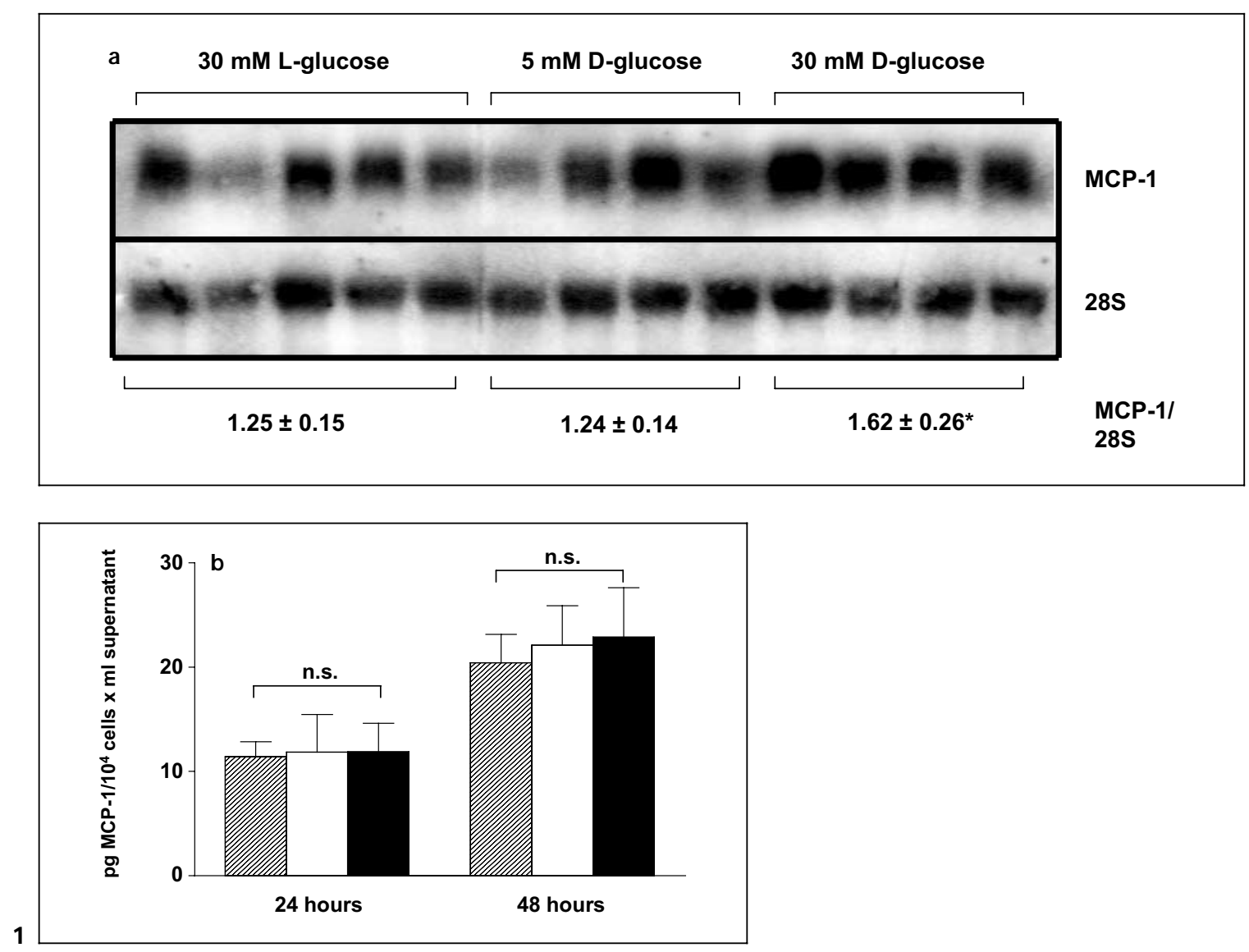

Fig. 1. a MCP-1 mRNA expression in glucose primed HMC. Confluent, 'growth-arrested' HMC were exposed to $5 \mathrm{~m} M D$-glucose (5), $30 \mathrm{~m} M D$-glucose (30) or $30 \mathrm{~m} M L$-glucose (L) in the absence of serum. Total cellular RNA of 4 separate experiments was extracted after $48 \mathrm{~h}$ and $10 \mu \mathrm{g}$ of RNA was subjected to formaldehyde-agarose gel electrophoresis, transferred to nylon membrane, and hybridized with digoxigenin-labeled RNA probes specific for MCP-1. Detection of the labeled probes was performed with digoxigenin-specific chemiluminescence detection reagents. Samples were analyzed by densitometry. The relative OD of the MCP- 1 bands were normalized using the $28 \mathrm{~S}$ bands as control. ${ }^{*} \mathrm{p}<0.05$ vs. $5 \mathrm{~m} M D$-glucose and $30 \mathrm{mM}$ $L$-glucose. b MCP-1 secretion in glucose primed HMC. Confluent, 'growth-arrested' HMC were exposed to $5 \mathrm{~m} M D$-glucose ( $\square$ ), $30 \mathrm{~m} M D$-glucose $(\square)$ or $30 \mathrm{~m} M L$-glucose $(\mathbb{Z})$ in the absence of serum for times up to $48 \mathrm{~h}$. Subsequently, the culture media were harvested and the concentrations of secreted MCP-1 were determined by ELISA. The data represent 6 individual experiments. All differences not significant.
Fig. 2. a CCR 2 mRNA expression in glucose primed HMC. Confluent, 'growth-arrested' HMC were exposed to $5 \mathrm{~m} M D$-glucose (5), $30 \mathrm{~m} M D$-glucose (30) or $30 \mathrm{~m} M L$-glucose (L) in the absence of serum. Total cellular RNA was extracted after $48 \mathrm{~h}$ and mRNAs for CCR2 and $\beta$-tubulin as reference examined by RT-PCR. Subsequently, PCR products were separated by electrophoresis on a $1.5 \%$ agarose gel. b Migration of $5 \mathrm{~m} M D$-glucose primed HMC towards MCP-1. Migration was assessed in type IV collagen-coated porous cell culture inserts. $5 \mathrm{mMD}$-glucose primed HMC were added to the upper chamber of the transwell and increasing concentrations of MCP-1 (3-90 ng/ml in resting medium) were added to the lower chamber. After $16 \mathrm{~h}$ cells that had migrated to the lower well were counted and expressed as a migration index (M. Index), calculated as the $\mathrm{X}$-fold increase in migration observed over the negative control (Medium). The data represent three independent experiments. c Effect of pertussis-toxin (PTX) on the MCP-1 triggered migration of $5 \mathrm{~m} M D$-glucose primed HMC. Migration was assessed as described in figure $2 \mathrm{~b}$. The figure shows the migration of $5 \mathrm{mM} \mathrm{D}$ glucose primed HMC treated with increasing doses of PTX (1$100 \mathrm{ng} / \mathrm{ml})$ in response to MCP-1 $(90 \mathrm{ng} / \mathrm{ml})$. The data represent three independent experiments. d Effect of $30 \mathrm{~m} M D$-glucose, vMIPII and (1-8del)MCP-1 on the MCP-1 triggered migration of HMC. Migration was assessed as described in figure $2 \mathrm{~b}$. The figure shows the migration of $5 \mathrm{~m} M D$-glucose primed HMC treated with vMIP-II $(1-100 \mathrm{ng} / \mathrm{ml})$ or $(1-8 \mathrm{del}) \mathrm{MCP}-1(10-1000 \mathrm{ng} / \mathrm{ml})$ in response to MCP-1 $(90 \mathrm{ng} / \mathrm{ml})$. Moreover, the migration of $30 \mathrm{mM} \mathrm{D}$-glucose primed HMC in response to MCP-1 $(90 \mathrm{ng} / \mathrm{ml})$ is shown. The data represent three independent experiments. 

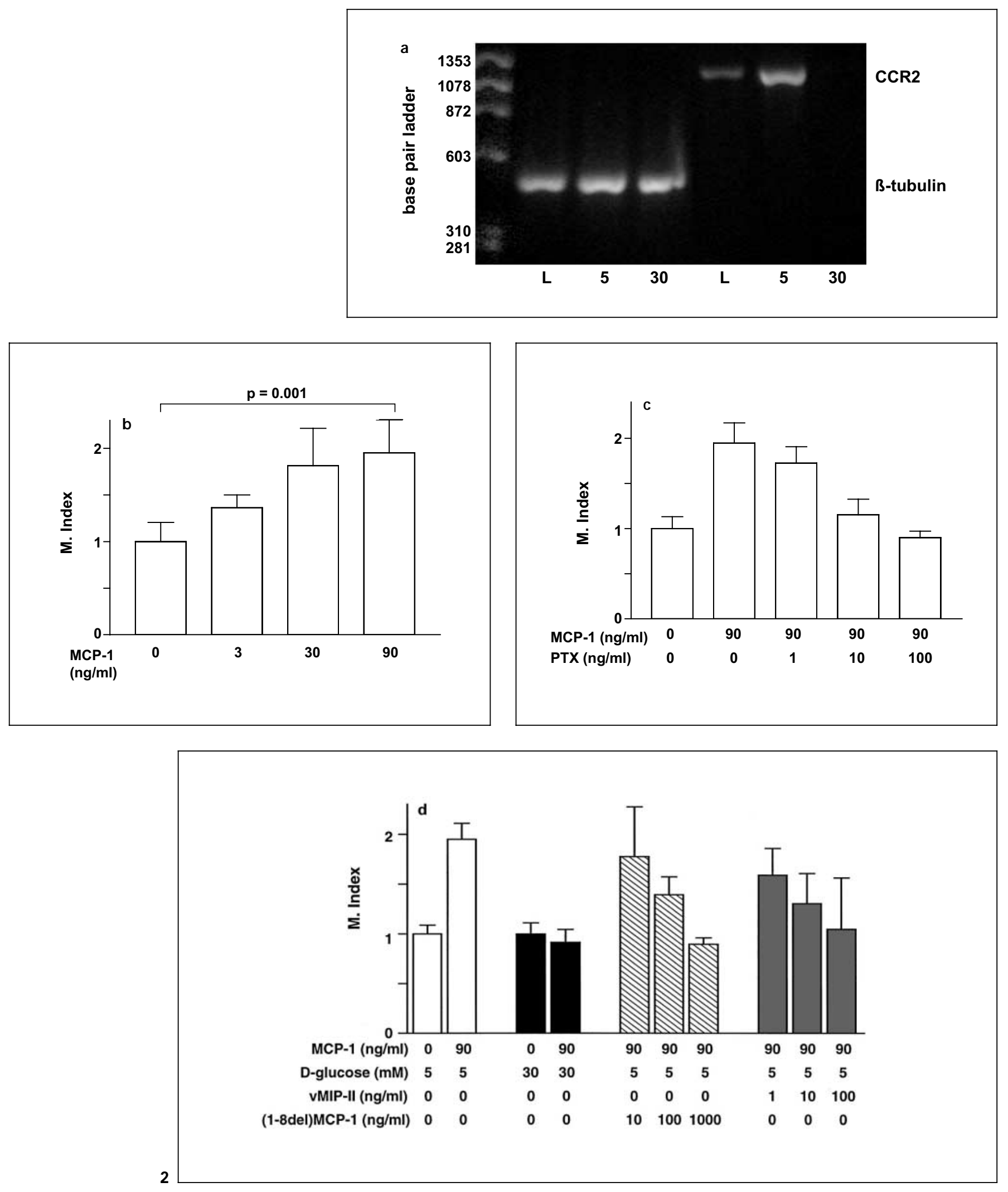
Fig. 3. a $\mathrm{MCP}-1$ secretion in glucose primed HMC after stimulation with TNFa (dose response). Confluent, 'growth-arrested' HMC were exposed to 5 ( $\square$ ) or $30 \mathrm{mM}$ $D$-glucose $(\square)$ in the absence of serum. After $24 \mathrm{~h}$ TNF $\alpha 0-500 \mathrm{U} / \mathrm{ml}$ was added to the cells. After $48 \mathrm{~h}$ the culture media were harvested and the concentrations of secreted MCP-1 were determined by ELISA. Each data point represents 6 independent determinations. ${ }^{*} \mathrm{p}=0.002$ vs. $5 \mathrm{~m} M D$-glucose. b MCP-1 secretion in glucose primed HMC after stimulation with $\mathrm{TNF} \alpha$ (time response). Confluent, 'growth-arrested' HMC were exposed to $5(\square)$ or $30 \mathrm{mM} D$-glucose ( $\square$ ) in the absence of serum. After $24 \mathrm{~h}$ TNFa $500 \mathrm{U} / \mathrm{ml}$ was added to the cells for 1-32 h. Subsequently, the culture media were harvested and the concentrations of secreted MCP-1 were determined by ELISA. Each data point represents 6 independent determinations. ${ }^{*} \mathrm{p}<0.02$ vs. $5 \mathrm{mM} D$-glucose. c MCP-1 mRNA expression in glucose primed HMC after stimulation with $\mathrm{TNF} \alpha$. Confluent, 'growth-arrested' HMC were exposed to $5 \mathrm{~m} M D$-glucose (5), $30 \mathrm{~m} M D$-glucose (30) or $30 \mathrm{~m} M L$-glucose (L) in the absence of serum. After $24 \mathrm{~h}$ TNFa $0-500$ $\mathrm{U} / \mathrm{ml}$ was added to the cells. Total cellular RNA was extracted after $48 \mathrm{~h}$ and $10 \mu \mathrm{g}$ of RNA was subjected to formaldehyde-agarose gel electrophoresis, transferred to nylon membrane, and hybridized with digoxigenin-labeled RNA probes specific for MCP-1. Detection of the labeled probes was performed with digoxigenin-specific chemiluminescence detection reagents. Samples were analyzed by densitometry. The relative OD of the MCP-1 bands were normalized using the $28 \mathrm{~S}$ bands as control.
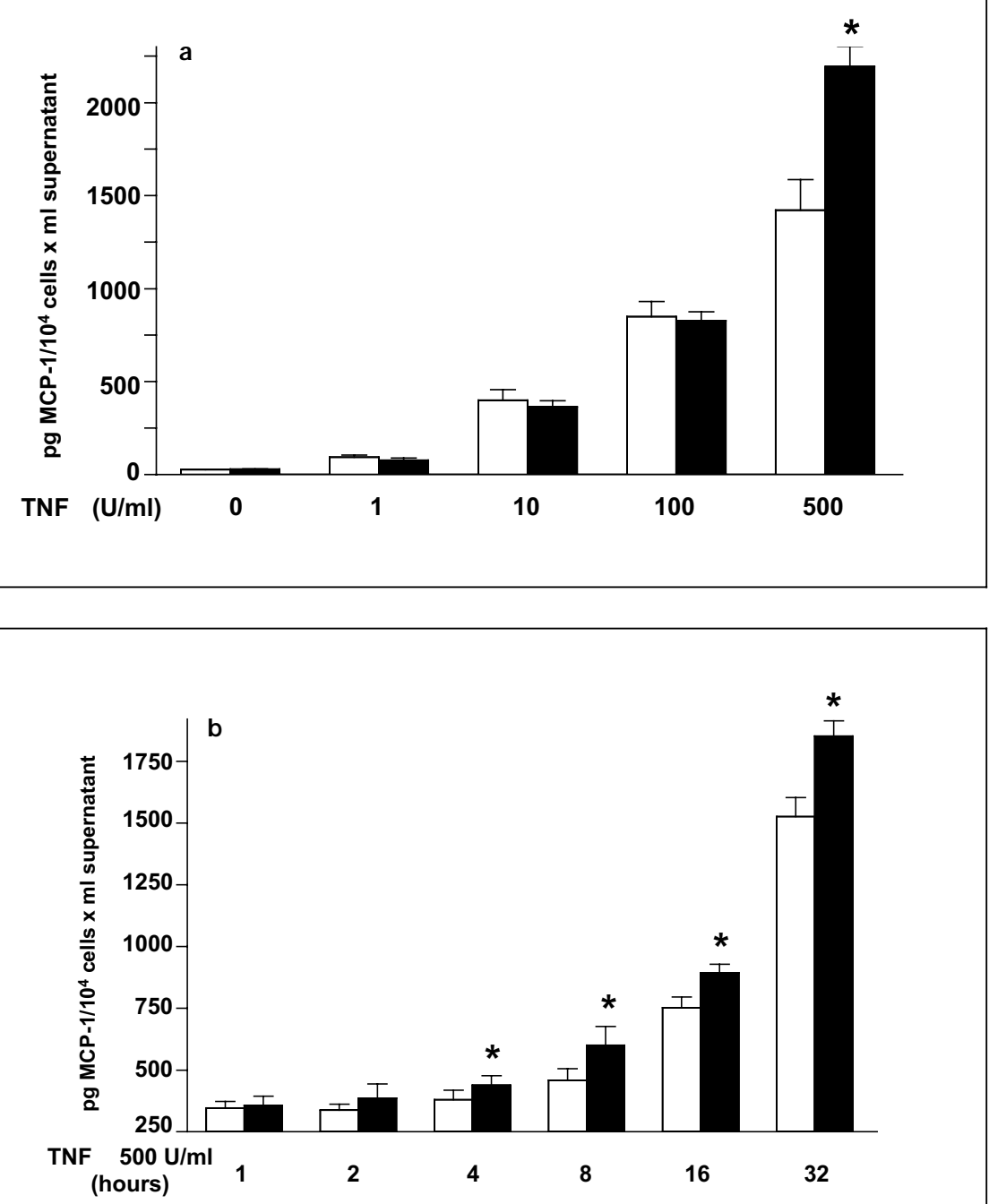

C

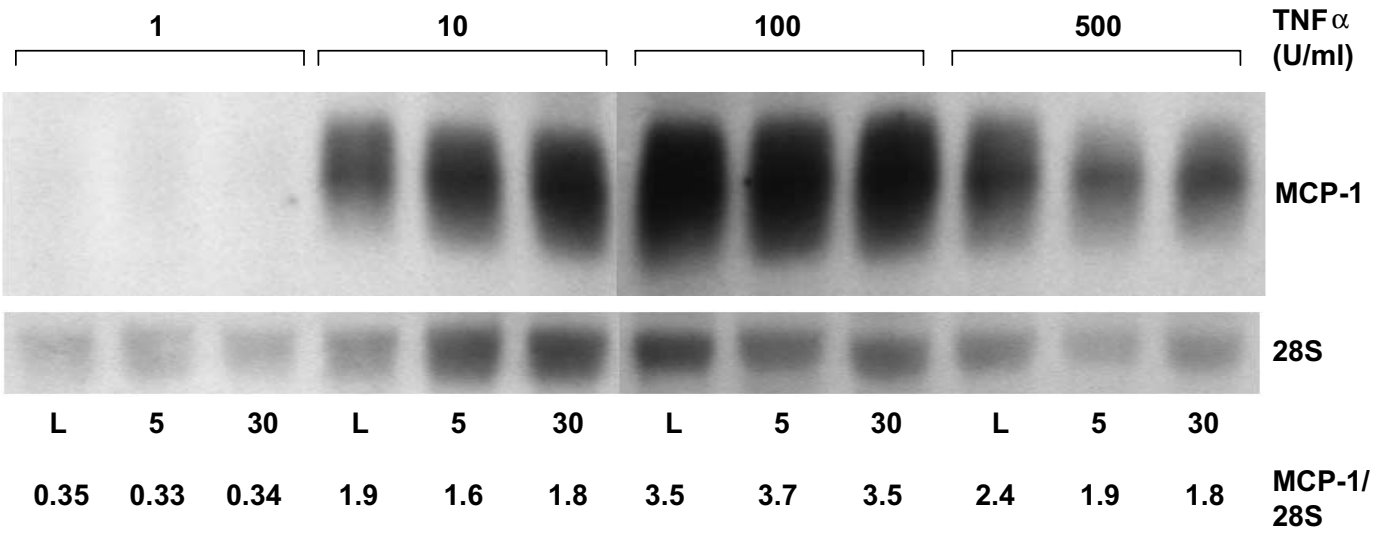




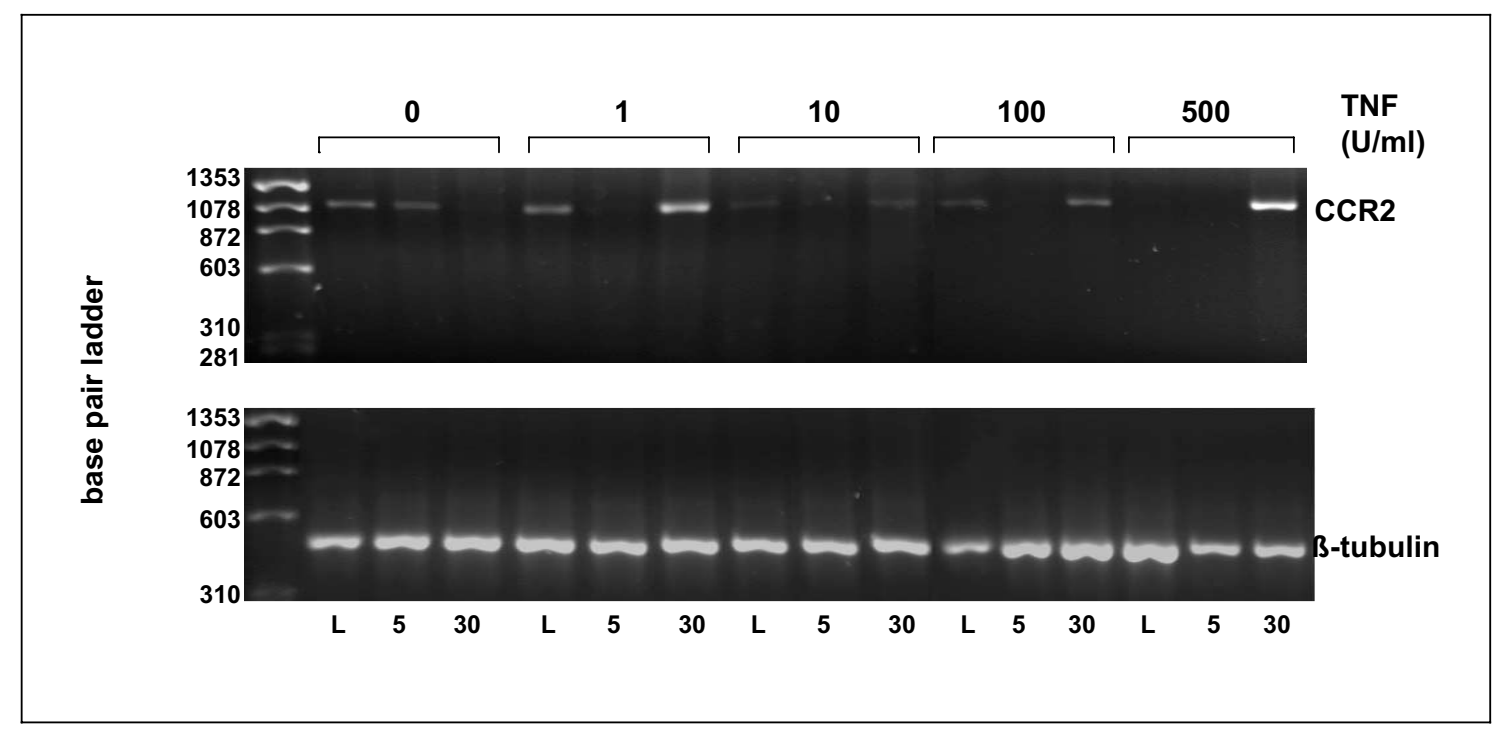

Fig. 4. CCR 2 mRNA expression in glucose primed HMC after stimulation with TNFa. Confluent, 'growth-arrested' HMC were exposed to $5 \mathrm{~m} M D$-glucose (5), $30 \mathrm{~m} M D$-glucose (30) or $30 \mathrm{~m} M L$-glucose (L) in the absence of serum. After $24 \mathrm{~h}$ TNF $\alpha$ 0-500 U/ml was added to the cells. Total cellular RNA was extracted after $48 \mathrm{~h}$ and mRNAs for CCR 2 and $\beta$-tubulin as reference examined by RT-PCR. Subsequently, PCR products were separated by electrophoresis on a $1.5 \%$ agarose gel.

\section{Exposure of HMC to High Glucose plus TNFa \\ Upregulates MCP-1 Protein Release through a \\ Mechanism That Does Not Involve Increased MCP-1 \\ mRNA Transcription}

We further investigated the effects of the additional proinflammatory stimulus $\mathrm{TNF} \alpha$ on glucose primed HMC. Stimulation with TNF $\alpha(500 \mathrm{U} / \mathrm{ml})$ led to a significantly higher increase in MCP-1 protein secretion in 30 as compared to $5 \mathrm{~m} M D$-glucose primed HMC while no difference was seen at lower TNF $\alpha$ doses (fig. 3a). The increase in MCP-1 protein secretion was observed from four hours on after stimulation with $\mathrm{TNF} \alpha(500 \mathrm{U} / \mathrm{ml}$; fig. 3b). There was, however, no difference in MCP-1 mRNA expression between 30 and $5 \mathrm{~m} M D$-glucose primed cells in the presence of TNF $\alpha$ (fig. 3c).

\section{Exposure of HMC to High Glucose plus TNFa}

Prevents the High Glucose Induced Downregulation of CCR2 $m R N A$

In the presence of TNF $\alpha$ CCR 2 mRNA expression was upregulated in $30 \mathrm{~m} M D$-glucose primed HMC while no CCR2 mRNA expression was observed in HMC exposed to $5 \mathrm{~m} M D$-glucose plus TNFa (fig. 4). As will be discussed in more detail below the expected enhancement of the migratory response of $30 \mathrm{~m} M D$-glucose primed HMC stimulated with TNF $\alpha$ could not be detected. On the con- trary, TNF $\alpha$ reduced migration of 5 as well as $30 \mathrm{~m} M D$ glucose primed HMC towards MCP-1 to $30 \%$ of unstimulated HMC medium controls.

\section{Discussion}

The present investigation shows that the ambient glucose concentration influences the expression of MCP-1 as well as its receptor CCR2 in primary human mesangial cells. The data demonstrate that high glucose alone leads to a slight increase in MCP-1 and simultaneous downregulation in CCR 2 mRNA expression. However, $30 \mathrm{~m} M D$ glucose did not induce a significant increase in MCP-1 protein secretion. Banba et al. [3] recently reported a slight increase in MCP-1 mRNA expression and protein production in $\mathrm{HMC}$ exposed to high glucose while others have reported a more than $50 \%$ increase in MCP-1 protein secretion by HMC exposed to high glucose alone [28]. However, in both studies experiments were carried out in the presence of fetal calf serum, 0.5 and $5 \%$, respectively $[3,28]$. It is conceivable that factors present in serum exert additional effects on HMC exposed to high glucose resulting in an increased production of MCP-1. As we have shown in the present study synergistic effects of high glucose and TNF $\alpha$ resulted in an increased MCP-1 pro- 
tein secretion in HMC. Another example of synergistic effects of high glucose and additional factors is the regulation of TGF- $\beta 1$ production in human proximal tubular epithelial cells where TGF- $\beta 1$ mRNA is induced by high glucose while only the addition of growth factors [29] or cytokines [30] leads to an increased TGF- $\beta 1$ protein secretion. In contrast in human peritoneal mesothelial cells, a direct stimulation of MCP-1 secretion by $50 \mathrm{mM}$ $D$-glucose alone has been described [31]. This may indicate that effects of high glucose on MCP-1 expression may differ in different cell types. Moreover, in mesothelial cells a higher glucose concentration, i.e. $50 \mathrm{~m} M D$-glucose, was used as compared to the studies carried out in mesangial and proximal tubular epithelial cells where cells were stimulated with 25-30 $\mathrm{m} M D$-glucose.

Our data demonstrate that while high glucose alone only increases MCP-1 mRNA expression, addition of the proinflammatory stimulus $\mathrm{TNF} \alpha$ results in a moderate but significantly higher increase in MCP-1 protein production in high as compared to $5 \mathrm{~m} M D$-glucose primed HMC. The observation that there is no difference in MCP-1 mRNA expression between 5 and $30 \mathrm{~m} M D$-glucose primed HMC in the presence of TNF $\alpha$ indicates that posttranscriptional mechanisms are involved in the increased MCP-1 protein secretion in $30 \mathrm{~m} M D$-glucose primed HMC stimulated with TNF $\alpha$. The data show that HMC may respond to certain proinflammatory stimuli in the presence of elevated glucose concentrations with an increased MCP-1 production which could possibly contribute to an increased recruitment of monocytes to the glomerulus. While the role of glomerular macrophage infiltration in the development of human diabetic nephropathy still remains to be elucidated, prominent macrophage infiltration has been described in renal biopsy specimens from patients with diabetic nephropathy [1]. Moreover, it has been demonstrated that not only the number of macrophages per glomerulus but also macrophage activation seems to increase with the severity of the glomerular lesion in human diabetic nephropathy [32]. Prominent macrophage infiltration in the kidneys of streptozotocin-treated rats [33, 34] was associated with an increased glomerular expression of MCP-1 [34] and a suppression of MCP-1 expression reduced glomerular macrophage recruitment [35]. Thus, it was suggested that glomerular macrophage infiltration may be involved in the pathological changes associated with diabetic nephropathy. These infiltrating cells may therefore be a source of proinflammatory cytokines which act upon resident cells such as mesangial cells. As only 30\% of all diabetic patients develop diabetic nephropathy, it is recognized that its pathogenesis is multifactorial rather than the sole result of hyperglycemia. Our findings suggest a more plausible hypothesis, namely that elevated glucose concentrations alone may be insufficient to initiate pathological changes but may prime the kidney for enhanced responses when exposed to other insults. Thus, in the presence of elevated glucose concentrations, inflammation and/or infection might be expected to have a greater impact than when they occur during euglycemia.

The observation that $5 \mathrm{mM} D$-glucose primed HMC downregulate CCR2 mRNA expression in the presence of $\mathrm{TNF} \alpha$ corresponds to findings in human monocytes where a rapid downregulation of CCR 2 by inflammatory stimuli such as lipopolysaccharides (LPS) and TNF $\alpha$ has been reported [36-38]. In monocytes/macrophages this receptor inhibition is regarded as a mechanism to arrest and retain recruited macrophages and to prevent chemokine scavenging by mononuclear phagocytes at sites of inflammation and tumor growth [38]. Recently, the downregulation of CCR 2 by bacterial endotoxin (LPS) in monocytes has been shown to be dependent upon tyrosine kinase activation and serine proteinase-mediated receptor degradation [37]. In HMC receptor inhibition may serve as a mechanism to protect the cell from autocrine effects of MCP-1 which might otherwise result in increased matrix accumulation and cell proliferation (see below). Our findings indicate that such a mechanism is impaired under conditions of high glucose and that the cell is therefore more susceptible to secreted MCP-1 in a diabetic milieu. A central finding of the current study was that HMC did migrate towards MCP-1 in a dose-dependent fashion. This MCP-1 triggered migration could be blocked by pertussis toxin, indicating the involvement of a pertussis-toxin-sensitive G-protein in this process. Chemokine activity is mediated through seven transmembrane domain receptors coupled to pertussis-toxin sensitive G-proteins [39] and CCR2 is a member of the Gprotein-coupled seven-transmembrane receptor superfamily [8]. In additional experiments, we could demonstrate that the MCP-1 triggered migration of HMC was inhibited by the broad-spectrum chemokine antagonist viral macrophage inflammatory protein (vMIP)-II as well as the CCR2 receptor antagonist (1-8del)MCP-1. vMIPII, encoded by human herpesvirus 8 (HHV8), binds with high affinity to a number of both CC and CXC chemokine receptors - acting as a potent antagonist of chemotaxis [40]. In contrast, (1-8del)MCP-1 is a specific CCR2 receptor antagonist generated by truncation of residues of MCP-1 that contribute to signalling through CCR2 resulting in a protein that cannot stimulate chemotaxis 
[41]. Our migration studies therefore indicate functional activity of CCR 2 expressed by HMC, although we cannot exclude that another yet unknown receptor for MCP-1 is involved in the MCP-1 triggered migration of HMC.

The observation that stimulation with TNF $\alpha$ reduced all HMC migration to levels below negative medium controls may be partly due to an upregulation of cellular adhesive properties by $\mathrm{TNF} \alpha$ - thereby overriding the chemotactic effect of MCP-1. More likely it is due to the well known effect of ligand-induced receptor desensitization. The latter mechanism has been described in detail for MCP-1 and its receptor CCR $2 b$ and explained by the activity of $\mathrm{G}$ protein-coupled receptor kinase 2 [42]. Thus, in our experimental situation TNF $\alpha$ induced MCP-1 molecules could readily occupy simultaneously induced CCR2 and lead to an uncoupling, which is responsible for reduced migration of HMC. Apart from leukocytes CCR2 expression has been described in vascular smooth muscle cells (VSMC), endothelial cells and fibroblasts while no reproducible CCR2 expression has been reported in a human mesangial cell line [15]. In VSMC and endothelial cells MCP-1 seems to induce cell proliferation and migration via CCR2 [10-12]. In pulmonary fibroblasts MCP-1 has been shown to directly stimulate the synthesis of profibrotic cytokines such as TGF- $\beta$ as well as matrix accumulation $[13,14]$. This was accompanied by an upregulation of CCR2 expression in fibroblasts derived from fibrotic pulmonary granulomas [13]. While the findings in pulmonary granuloma models $[13,14]$ point to a role for CCR2 in fibrogenesis, an increased severity of glomerulonephritis in CCR2 knockout mice has recently been reported - raising the possibility that a CCR 2 gene product may be involved in the amelioration of glomerulonephritis [43]. Therefore, it remains to be elucidated what the consequences of a mesangial CCR 2 expression in glomerular diseases, such as diabetic nephropathy, might be.

In summary, we have shown that high glucose alone induces MCP-1 mRNA expression while the additional proinflammatory stimulus $\mathrm{TNF} \alpha$ leads to a significantly higher increase in $\mathrm{MCP}-1$ protein production in high as compared to $5 \mathrm{~m} M D$-glucose primed HMC. Moreover, we have demonstrated that primary human mesangial cells show a functionally active MCP-1 receptor expression which is influenced by the ambient glucose concentration and can result in the formation of an autocrine MCP-1 signalling pathway in the presence of combined hyperglycemia and inflammatory conditions.

\section{Acknowledgements}

The technical help of Juliane von der Ohe is gratefully acknowledged. This study was supported by a stipend of the German Research Foundation (Deutsche Forschungsgemeinschaft; Graduiertenkolleg 'Charakterisierung regulatorischer Peptide und ihrer Zielproteine') to U.J.

\section{References}

1 Furuta T, Saito T, Ootaka T, Soma J, Obara K, Abe K, Yoshinaga K: The role of macrophages in diabetic glomerulosclerosis. Am J Kidney Dis 1993;21:480-485.

2 Rovin BH, Doe N, Tan LC: Monocyte chemoattractant protein-1 levels in patients with glomerular disease. Am J Kidney Dis 1996;27: 640-646.

3 Banba N, Nakamura T, Matsumura M, Kuroda H, Hattori Y, Kasai K: Possible relationship of monocyte chemoattractant protein-1 with diabetic nephropathy. Kidney Int 2000;58: 684-690.

4 Schwarz M, Radeke HH, Resch K, Uchiechowski P: Lymphocyte-derived cytokines induce sequential expression of monocyte- and $\mathrm{T}$ cell-specific chemokines in human mesangial cells. Kidney Int 1997;52:1521-1531.

5 Ihm CG: Monocyte chemotactic peptide in diabetic nephropathy. Kidney Int 1997;52:S20S22.

6 Rovin BH, Tan LC: LDL stimulates mesangial fibronectin production and chemoattractant expression. Kidney Int 1993;43:218-225.
7 Grandaliano G, Valente AJ, Abboud HE: A novel biologic activity of thrombin: Stimulation of monocyte chemotactic protein production. J Exp Med 1994;179:1737-1741.

8 Sallusto F, Lanzavecchia A, Mackay CR: Chemokines and chemokine receptors in T-cell priming and $\mathrm{Th} 1 / \mathrm{Th} 2$-mediated responses. Immunol Today 1998;19:568-574.

9 Frade JMR, Mellado M, del Real G, GutierrezRamos JC, Lind P, Martinez AC: Characterization of the CCR2 chemokine receptor: Functional CCR2 receptor expression in B cells. $\mathbf{J}$ Immunol 1997; 159:5576-5584

10 Hayes IM, Jordan NJ, Towers S, Smith G, Paterson JR, Earnshaw JJ, Roach AG, Westwick J, Williams RJ: Human vascular smooth muscle cells express receptors for CC chemokines. Arterioscler Thromb Vasc Biol 1998;18: 397-403.
11 Salcedo R, Ponce ML, Young HA, Wasserman K, Ward JM, Kleinman HK, Oppenheim JJ, Murphy WJ: Human endothelial cells express CCR2 and respond to MCP-1: Direct role of MCP-1 in angiogenesis and tumor progression. Blood 2000;96:34-40.

12 Weber KS, Nelson PJ, Grone HJ, Weber C: Expression of CCR2 by endothelial cells: Implications for MCP-1 mediated wound injury repair and in vivo inflammatory activation of endothelium. Arterioscler Thromb Vasc Biol 1999; 19:2085-2093.

13 Hogaboam CM, Bone-Larson CL, Lipinski S, Lukacs NW, Chensue SW, Strieter RM, Kunkel SM: Differential Monocyte chemoattractant protein-1 and chemokine receptor 2 expression by murine lung fibroblasts derived from Th1- and Th2-type pulmonary granuloma models. J Immunol 1999; 163:2193-2201.

14 Gharaee-Kermani M, Denholm EM, Phan SH: Costimulation of fibroblast collagen and transforming growth factor beta 1 gene expression by monocyte chemoattractant protein-1 via specific receptors. J Biol Chem 1996;271: 17779-17784. 
15 Banas B, Luckow B, Möller M, Klier C, Nelson PJ, Schadde E, Brigl M, Halevy D, Holthöffer H, Reinhart B, Schlöndorff D: Chemokine and chemokine receptor expression in an novel human mesangial cell line. J Am Soc Nephrol 1999;10:2314-2322.

16 Radeke HH, Meier B, Topley N, Floege J, Habermehl GG, Resch K: Interleukin- $\alpha$ and tumor necrosis factor- $\alpha$ induce oxygen radical production in mesangial cells. Kidney Int 1990; 37:767-775.

17 Radeke HH, Gessner JE, Uchiechowski P, Mägert H-J, Schmidt RE, Resch K: Intrinsic human glomerular mesangial cells can express receptors for IgG complexes (hFc $\gamma$ RIII-A) and the associated FceRI $\gamma$-chain. J Immunol 1994; 153:1281-1292.

18 Alpers CE, Hudkins KL, Gown AM, Johnson RJ: Enhanced expression of 'muscle-specific' actin in glomerulonephritis. Kidney Int 1992; 41:1134-1142.

19 Radeke HH, Resch K: The inflammatory function of renal glomerular mesangial cells and their interaction with the cellular immune system. Clin Invest 1992;70:825-842.

20 Floege J, Topley N, Wessel K, Kaever V, Radeke $\mathrm{HH}$, Hoppe J, Kishimoto T, Resch K: Monokines and platelet-derived growth factor modulate prostanoid production in growtharrested human mesangial cells. Kidney Int 1990;37:859-869.

21 Radeke HH, Cross AR, Hancock JT, Jones OTG, Nakamura M, Kaever V, Resch K: Functional expression of NADPH oxidase components $(\alpha-$ and $\beta$-subunits of cytochrome b558 and $45-\mathrm{kD}$ flavoprotein) by intrinsic human glomerular mesangial cells. J Biol Chem 1991; 266:21025-21029.

22 Francki A, Uciechowski P, Floege J, von der Ohe J, Resch K, Radeke HH: Autocrine growth regulation of human glomerular mesangial cells is primarily mediated by basic fibroblast growth factor. Am J Pathol 1994;147:13721382 .

23 Uciechowski P, Schwarz M, Gessner E, Schmidt RE, Resch K, Radeke HH: IFN- $\gamma$ induces the high affinity Fc receptor I for $\mathrm{IgG}$ (CD 64) on human glomerular mesangial cells. Eur J Immunol 1998;28:2928-2935.

24 Yamagami S, Tokuda Y, Ishii K, Tanaka H, Endo N: cDNA cloning and functional expression of a human monocyte chemoattractant protein 1 receptor. Biochem Biophys Res Commun 1994;202:1156-1162.
25 Marchand P, Resch K, Radeke HH: Selective inhibition of monocyte chemoattractant protein-1 gene expression in human embryonal kidney cells by specific triple helix-forming oligonucleotides. J Immunol 2000;164:20702076.

26 Beall CJ, Breckenridge SM, Chakravarty L, Kolattukudy PE: Expression of human monocyte chemoattractant protein-1 in the yeast $P i$ chia pastoris. Protein Expr Purif 1998;12:145150.

27 Reid S, Ritchie A, Boring L, Gosling J, Cooper S, Hangoc G, Charo IF, Broxmeyer HE: Enhanced myeloid progenitor cell cycling and apoptosis in mice lacking the chemokine receptor, CCR2. Blood 1999;93:1524-1533.

28 Ihm CG, Park JK, Hong SP, Lee TW, Cho BS, Kim MJ, Cha DR, Ha H: A high glucose concentration stimulates the expression of monocyte chemotactic peptide 1 in human mesangial cells. Nephron 1998;79:33-37.

29 Phillips AO, Steadman R, Topley N, Williams JD: Elevated $D$-glucose concentrations modulate TGF- $\beta 1$ synthesis by human cultured renal proximal tubular epithelial cells: The permissive role of platelet-derived growth factor. Am J Pathol 1995;147:362-373.

30 Phillips AO, Topley N, Steadman R, Morrisey $\mathrm{K}$, Williams JD: Induction of TGF- $\beta 1$ synthesis in $D$-glucose primed human proximal tubular epithelial cells by IL- $1 \beta$ and TNF $\alpha$. Kidney Int 1996;50:1546-1554.

$31 \mathrm{Ha} \mathrm{H}$, Lee HB: Effect of high glucose on peritoneal mesothelial cell biology. Perit Dial Int 2000;20:S15-S18.

32 Uesugi N, Sakata N, Horiuchi S, Nagai R, Takeya M, Meng J, Saito T, Takebayash S: Glycoxidation-modified macrophages and lipid peroxidation product are associated with the progression of human diabetic nephropathy. Am J Kidney Dis 2001;38:1016-1025.

33 Young BA, Johnson RJ, Alpers CE, Eng CE, Ghordon K, Floege J, Couser W: Cellular events in the evolution of experimental diabetic nephropathy. Kidney Int 1995;47:935-944.

34 Sassy-Prigent C, Heudes D, Mandet C, Belair MF, Michel O, Perderau B, Bariety J, Bruneval $\mathrm{P}$ : Early glomerular macrophage recruitment in streptozotocin-induced diabetic rats. Diabetes 2000;49:466-475.

35 Kato S, Luyckx VA, Ots M, Lee KW, Ziai F, Troy JL, Brener BM, MacKenzie HS: Reninangiotensin blockade lowers MCP-1 expression in diabetic rats. Kidney Int 1999;56:10371048 .
36 Weber C, Draude G, Weber KS, Wubert J, Lorenz RL, Weber PC: Downregulation by tumor necrosis factor-alpha of monocyte CCR2 expression and monocyte chemotactic-1-induced transendothelial migration is antagonized by oxidized low-density lipoprotein: A potential mechanism of monocyte retention in atherosclerotic lesions. Atherosclerosis 1999;145: $115-123$.

$37 \mathrm{Xu}$ L, Khandaker MH, Barlic J, Ran L, Borja ML, Madrenas J, Rahimpour R, Chen K, Mitchell G, Tan CM, DeVries M, Feldman RD, Kelvin DJ: Identification of a novel mechanism for endotoxin-mediated down-modulation of CC chemokine receptor expression. Eur J Immunol 2000;30:227-235.

38 Sica A, Caccani A, Botazzi B, Bernasconi S, Allavena P, Gaetano B, Fei F, LaRosa G, Scotton C, Balkwill F, Mantovani A: Defective expression of the monocyte chemotactic protein-1 receptor CCR2 in macrophages associated with human ovarian carcinoma. J Immunol 2000;164:733-738.

39 Premack BA, Schall TJ: Chemokine receptors: Gateways to inflammation and infection. Nat Med 1996;2:1174-1178.

40 Kledal TN, Rosenkilde MM, Coulin F, Simmons G, Johnsen AH, Alouani S, Power CA, Luttichau HR, Gerstoft J, Clapham PR, ClarkLewis I, Wells TNC, Schwartz TW: A broadspectrum chemokine antagonist encoded by Kaposi's sarcoma-associated herpesvirus. Science 1997;277:1656-1659.

41 Jarnagin K, Grunberger D, Mulkins M, Wong B, Hemmerich S, Paavola C, Bloom A, Bhakta S, Diehl F, Freedman R, McCarley D, Polsky I, Ping-Tsou A, Kosaka A, Handel TM: Identification of surface residues of the monocyte chemotactic protein 1 that affect signaling through the receptor CCR2. Biochemistry 1999;38: 16167-16177.

42 Aragay AM, Mellado M, Frade JMR, Martin AM, Jimenez MC, Martinez-AC, Mayor F Jr: Monocyte chemoattractant protein-1-induced CCR2B receptor desensitization mediated by the $\mathrm{G}$ protein-coupled receptor kinase 2. Proc Natl Acad Sci USA 1998;95:2985-2990.

43 Bird JE, Giancarli MR, Kurihara T, Kowala MC, Valentine MT, Gitlitz PH, Pandya DG, French MH, Durham SK: Increased severity of glomerulonephritis in C-C chemokine receptor 2 knockout mice. Kidney Int 2000;57:129136. 